\title{
Fibroblast Growth Factor 1 Reduces Pulmonary Vein and Atrium Arrhythmogenesis via Modification of Oxidative Stress and Sodium/Calcium Homeostasis
}

\section{OPEN ACCESS}

Edited by:

Irena Levitan,

University of llinois at Chicago,

United States

Reviewed by:

Liang Hong,

University of Illinois at Chicago,

United States

Peipei Zhang,

Case Western Reserve University,

United States

*Correspondence:

Yi-Jen Chen

yjchen@tmu.edu.tw

†These authors have contributed equally to this work and share first authorship

Specialty section:

This article was submitted to Cardiac Rhythmology,

a section of the journal

Frontiers in Cardiovascular Medicine

Received: 17 November 2021

Accepted: 21 December 2021

Published: 18 January 2022

Citation:

Lu Y-Y, Cheng C-C, Huang S-Y, Chen Y-C, Kao Y-H, Lin Y-K, Higa S,

Chen S-A and Chen Y-J (2022) Fibroblast Growth Factor 1 Reduces

Pulmonary Vein and Atrium Arrhythmogenesis via Modification of Oxidative Stress and

Sodium/Calcium Homeostasis.

Front. Cardiovasc. Med. 8:813589.

doi: 10.3389/fcvm.2021.813589

\begin{abstract}
Yen-Yu Lu ${ }^{1,2 \dagger}$, Chen-Chuan Cheng ${ }^{3 \dagger}$, Shih-Yu Huang ${ }^{2,4,5}$, Yao-Chang Chen ${ }^{6}$, Yu-Hsun Kao ${ }^{7,8}$, Yung-Kuo Lin ${ }^{9,10}$, Satoshi Higa ${ }^{11}$, Shih-Ann Chen ${ }^{12,13}$ and Yi-Jen Chen ${ }^{7,9 *}$

${ }^{1}$ Division of Cardiology, Department of Internal Medicine, Sijhih Cathay General Hospital, New Taipei City, Taiwan, ${ }^{2}$ School of Medicine, College of Medicine, Fu-Jen Catholic University, New Taipei City, Taiwan, ${ }^{3}$ Division of Cardiology, Chi-Mei Medical Center, Tainan City, Taiwan, ${ }^{4}$ Division of Cardiac Electrophysiology, Cardiovascular Center, Cathay General Hospital, Taipei, Taiwan, ${ }^{5}$ Post-Baccalaureate Medicine, College of Life Science, National Tsing Hua University, Hsinchu City, Taiwan, ${ }^{6}$ Department of Biomedical Engineering, National Defense Medical Center, Taipei, Taiwan, ${ }^{7}$ Graduate Institute of Clinical Medicine, College of Medicine, Taipei Medical University, Taipei, Taiwan, ${ }^{8}$ Department of Medical Education and Research, Wan Fang Hospital, Taipei Medical University, Taipei, Taiwan, ${ }^{9}$ Cardiovascular Research Center, Wan Fang Hospital, Taipei Medical University, Taipei, Taiwan, ${ }^{10}$ Division of Cardiology, Department of Internal Medicine, School of Medicine, College of Medicine, Taipei Medical University, Taipei, Taiwan, ${ }^{11}$ Cardiac Electrophysiology and Pacing Laboratory, Division of Cardiovascular Medicine, Makiminato Central Hospital, Okinawa, Japan, ${ }^{12}$ Heart Rhythm Center and Division of Cardiology, Department of Medicine, Taipei Veterans General Hospital, Taipei, Taiwan, ${ }^{13}$ Cardiovascular Center, Taichung Veterans General Hospital, Taichung, Taiwan
\end{abstract}

Rationale: Atrial fibrillation is a critical health burden. Targeting calcium $\left(\mathrm{Ca}^{2+}\right)$ dysregulation and oxidative stress are potential upstream therapeutic strategies. Fibroblast growth factor (FGF) 1 can modulate $\mathrm{Ca}^{2+}$ homeostasis and has antioxidant activity. The aim of this study was to investigate whether FGF1 has anti-arrhythmic potential through modulating $\mathrm{Ca}^{2+}$ homeostasis and antioxidant activity of pulmonary vein (PV) and left atrium (LA) myocytes.

Methods: Patch clamp, western blotting, confocal microscopy, cellular and mitochondrial oxidative stress studies were performed in isolated rabbit PV and LA myocytes treated with or without FGF1 ( 1 and $10 \mathrm{ng} / \mathrm{mL}$ ). Conventional microelectrodes were used to record electrical activity in isolated rabbit PV and LA tissue preparations with and without FGF1 (3 $\mu \mathrm{g} / \mathrm{kg}$, i.v.).

Results: FGF1-treated rabbits had a slower heart rate than that observed in controls. PV and LA tissues in FGF1-treated rabbits had slower beating rates and longer action potential duration than those observed in controls. Isoproterenol $(1 \mu \mathrm{M})$-treated PV and LA tissues in the FGF1-treated rabbits showed less changes in the increased beating rate and a lower incidence of tachypacing $(2 \mathrm{~Hz})$-induced burst firing than those observed in controls. FGF1 (10 ng/mL)-treated PV and LA myocytes had less oxidative stress and $\mathrm{Ca}^{2+}$ transient than those observed in controls. Compared to controls, FGF1 (10 ng/mL) decreased $I_{\mathrm{Na}-\mathrm{L}}$ in PV myocytes and lowered $I_{\mathrm{to}}, I_{\mathrm{Kr} \text {-tail }}$ in LA myocytes. Protein kinase $C(P K C) \varepsilon$ inhibition abolished the effects of FGF1 on the ionic currents of LA and PV myocytes. 


\section{Conclusion: FGF1 changes PV and LA electrophysiological characteristics possibly via modulating oxidative stress, $\mathrm{Na}^{+} / \mathrm{Ca}^{2+}$ homeostasis, and the $\mathrm{PKC} \varepsilon$ pathway.}

Keywords: atrial fibrillation, calcium regulation, fibroblast growth factor 1 , oxidative stress, pulmonary vein

\section{INTRODUCTION}

Fibroblast growth factor (FGF) 1, a signaling protein secreted mainly in the paracrine system, may be produced by cardiomyocytes (1). Animal and cellular studies have shown that FGF1 plays a cardioprotective role during ischemia and reperfusion conditions $(2,3)$. FGF23, a member of the FGF family, has several cardiovascular effects and can directly change cardiac electrical activity $(4,5)$. The overexpression of FGF1 may protect against cardiac injury through the FGF receptor (FGFR)mediated signaling and the protein kinase C (PKC)-dependent pathway $(3,6)$.

Atrial fibrillation (AF) is the most common type of cardiac arrhythmia that causes heart failure and cardiovascular events (7). Enhanced trigger activity from pulmonary vein (PV) ectopic foci is critical for the genesis of $\operatorname{AF}(8,9)$. Moreover, the left atrium (LA) is the most vital substrate of AF (10). The FGF1-FGFR system might play an important role in pulmonary vascular remodeling via chronic inflammation, fibrosis, or heart tissue repair, which has been demonstrated in obstructive lung disease $(11,12)$. FGF-1 protects cardiomyocytes from oxidative damage with hydrogen peroxide, which may enhance PV and atrial remodeling in the pathogenesis and perpetuation of $\mathrm{AF}$ (13-15). Accordingly, FGF may play a critical role in the pathogenesis of $\mathrm{AF}$, and different FGF subtypes may have discrepant effects on PV and atrial arrhythmogenesis.

Calcium $\left(\mathrm{Ca}^{2+}\right)$ regulation may induce the electrical remodeling of the $\mathrm{PV}$ and the atrium leading to abnormal cellular conduction properties that contribute to the pathogenesis of $\mathrm{AF}$ $(16,17)$. Moreover, the inhibition of $\mathrm{PKC}$ and $\mathrm{Ca}^{2+}$ regulatory proteins, which influence the signaling of cardiac protection via FGF family members, reverse electrical remodeling in FGF family member-treated PV myocytes $(4,6,18)$. In addition, FGF1 can increase the cardiac expression of atrial natriuretic factor, which is blocked by PKC inhibitors $(19,20)$. Therefore, the purpose of this study was to investigate whether FGF1 changes the electrical properties of the AF trigger (PV) and substrate (LA) and evaluate the potential underlying mechanisms.

\section{MATERIALS AND METHODS}

\section{Electropharmacological Experiments in PV and LA Tissues in FGF1-Treated Rabbits}

This study was approved by the local ethics review board (No. IACUC-20-365). The Male New Zealand white rabbits $(2.0 \sim 3.0 \mathrm{~kg}$ ) were received FGF1 (3 $\mu \mathrm{g} / \mathrm{kg}$, Sigma Aldrich, GF431) or vehicles intravenously $24 \mathrm{~h}$ before euthanasia by anesthetized using an intramuscular injection of xylazine hydrochloride $(12 \mathrm{mg} / \mathrm{kg})$ and inhaled overdose of isoflurane (2.0-2.5\% in oxygen) from a precision vaporizer as described previously (13). The anesthesia dose was confirmed as adequate because the rabbits did not exhibit corneal reflexes and motor responses to pain stimuli induced with a scalpel tip. Electrocardiograms of the rabbits were recorded from standard lead II limb leads via a bio-amplifier (AD Instruments, Castle Hill, Australia), connected to a polygraph recorder (ML 845 Powerlab, AD Instruments) in a restrained condition for $6 \mathrm{~h}$ before euthanasia (21).

PVs and LA tissues were isolated from all rabbits after euthanasia as described previously (22). The tissue preparations were bathed in Tyrode's solution at $37^{\circ} \mathrm{C}$ containing $137 \mathrm{mM}$ $\mathrm{NaCl}, 4 \mathrm{mM} \mathrm{KCl}, 15 \mathrm{mM} \mathrm{NaHCO}_{3}, 0.5 \mathrm{mM} \mathrm{NaH}_{2} \mathrm{PO}_{4}, 0.5 \mathrm{mM}$ $\mathrm{MgCl}_{2}, 2.7 \mathrm{mM} \mathrm{CaCl}_{2}$, and $11 \mathrm{mM}$ dextrose. The tissues were superfused at a constant rate $(3 \mathrm{~mL} / \mathrm{min})$ with Tyrode's solution, which was saturated with a gas mixture of $97 \% \quad \mathrm{O}_{2}$ and $3 \% \mathrm{CO}_{2}$. The transmembrane action potentials (APs) of the PV and LA tissues were recorded using machine-pulled glass capillary microelectrodes filled with $3 \mathrm{M} \mathrm{KCl}$, and the tissue preparations were connected to a World Precision Instrument model FD223 electrometer (FL, USA) (23). The electrical and mechanical events were simultaneously displayed on a Gould 4072 oscilloscope (OH, USA) and Gould TA11 recorder (2426). Electrical stimuli were applied using a Grass S88 stimulator through a Grass SIU5B stimulus isolation unit.

The resting membrane potential (RMP) was measured during the period between the last repolarization and onset of the subsequent AP. The AP amplitude (APA) was obtained from the RMP to the peak of AP depolarization. The AP duration (APD) at 20,50, and $90 \%$ repolarization of the amplitude was measured and recorded as $\mathrm{APD}_{20}, \mathrm{APD}_{50}$, and $\mathrm{APD}_{90}$, respectively. APs were analyzed for maximum upstroke velocity $\left(\mathrm{dV} / \mathrm{dt}_{\max }\right)$, early and late diastolic depolarization (EDD and LDD) (27). Burst firing was defined as the occurrence of an accelerated spontaneous potential with sudden onset and termination. The RMP, APA, and APD were measured under spontaneous beating of PV or $2-\mathrm{Hz}$ pacing of the LA tissues. The PV tissues were analyzed before and after stimulation with isoproterenol $(1 \mu \mathrm{M})$ to observe burst firing. In addition, the LA tissues were analyzed before and after stimulation with isoproterenol $(1 \mu \mathrm{M})$ to observe burst firing with or without high-frequency burst pacing $(20 \mathrm{~Hz})$ for $1 \mathrm{~s}$.

\section{Patch Clamp Experiments in Isolated Single Cardiomyocytes Preparation}

Single PV and LA cardiomyocytes were enzymatically dissociated through the same procedure described previously $(28,29)$. In briefly, the heart and lungs were rapidly excised following midline thoracotomy after heparin $(1,000$ units $/ \mathrm{kg})$ was intravenously administered. Proximal PVs and LA were cut away from the 
atrium and lung. They were gently shaken in $5 \sim 10 \mathrm{ml}$ of $\mathrm{Ca}^{2+}$. free oxygenated Tyrode's solution until single cardiomyocytes were obtained. The solution was then gradually changed to oxygenated normal Tyrode's solution. Cells were allowed to stabilize in the bath for at least $30 \mathrm{~min}$ before the experiments.

Single cardiomyocytes with spontaneous activity were identified by the presence of constant beating during perfusion with Tyrode's solution. Then, single PV and LA myocytes were treated in the control and FGF1 ( 1 and $10 \mathrm{ng} / \mathrm{mL}$; Sigma Aldrich, GF431) for 4-6h are harvested for further experiments with or without PKC $\varepsilon$ inhibitor peptide ( $\varepsilon$ V1-2, $200 \mathrm{nM}$, Cayman).

The whole-cell patch clamp experiment was performed in the isolated PVs and LA myocytes by using an Axopatch 200B amplifier (Axon Instruments, Foster City, CA, USA) at $35 \pm 1^{\circ} \mathrm{C}$ $(17,30)$. Borosilicate glass electrodes (o.d., $1.8 \mathrm{~mm}$ ) with a tip resistance of 3-5 $\mathrm{M} \Omega$ were used. Before the formation of the membrane-pipette seal, the tip potentials were zeroed in Tyrode's solution. The junction potentials between the bath and pipette solution $(9 \mathrm{mV})$ were corrected for the AP recordings.

APs were recorded in the current-clamp mode, and the ionic currents were recorded in the voltage-clamp mode. APs of LA myocytes were elicited in cells through brief current pulses at $1 \mathrm{~Hz}$. The ionic currents were recorded at an approximately similar period (3-5 min) after rupture or perforation by amphotericin B to avoid decay of ion channel activity over time. A small hyperpolarizing step from a holding potential of $-50 \mathrm{mV}$ to a test potential of $-55 \mathrm{mV}$ for $80 \mathrm{~ms}$ was delivered at the beginning of each experiment. The area under the capacitative current curve was divided by the applied voltage step to calculate the total cell capacitance. Normally, series resistance $\left(R_{S}\right)$ was electronically compensated by $60-80 \%$.

The sodium $\left(\mathrm{Na}^{+}\right)$current $\left(I_{\mathrm{Na}}\right)$ was recorded by using 40 msec. pulses from a holding potential of $-120 \mathrm{mV}$ to the test potentials varying between -80 and $0 \mathrm{mV}$ in $5 \mathrm{mV}$ increments at a frequency of $3 \mathrm{~Hz}$ at room temperature $\left(25 \pm 1^{\circ} \mathrm{C}\right)$. The external solution contained: $5 \mathrm{mM} \mathrm{NaCl}, 133 \mathrm{mM} \mathrm{CsCl}, 2 \mathrm{mM}$ $\mathrm{MgCl}_{2}, 1.8 \mathrm{mM} \mathrm{CaCl}, 0.002 \mathrm{mM}$ nifedipine, $5 \mathrm{mM}$ HEPES and $5 \mathrm{mM}$ glucose $(\mathrm{pH}$ 7.3). Micropipettes were filled with a solution containing (in $\mathrm{mM}$ ) $133 \mathrm{mM} \mathrm{CsCl}, 5 \mathrm{mM} \mathrm{NaCl}, 10 \mathrm{mM}$ EGTA, $5 \mathrm{mM}$ MgATP, $20 \mathrm{mM}$ TEACl and $5 \mathrm{mM}$ HEPES ( $\mathrm{pH} 7.3$ with $\mathrm{CsOH}$ ).

The late $\mathrm{Na}^{+}$current $\left(I_{\mathrm{Na}-\text { Late }}\right)$ included a step/ramp protocol ( $-100 \mathrm{mV}$ stepping to $+20 \mathrm{mV}$ for $100 \mathrm{~ms}$, then ramping back to $-100 \mathrm{mV}$ over $100 \mathrm{~ms}$ ) at room temperature with an external solution containing $130 \mathrm{mM} \mathrm{NaCl}, 5 \mathrm{mM} \mathrm{CsCl}, 1 \mathrm{mM} \mathrm{MgCl}$, $1 \mathrm{mM} \mathrm{CaCl}_{2}, 10 \mathrm{mM}$ HEPES, and $10 \mathrm{mM}$ glucose; $\mathrm{pH}$ was adjusted to 7.3 using $\mathrm{NaOH}$. Micropipettes were filled with a solution containing $130 \mathrm{mM} \mathrm{CsCl}, 4 \mathrm{mM} \mathrm{Na}$ ATP, $1 \mathrm{mM} \mathrm{MgCl}_{2}$, $10 \mathrm{mM}$ EGTA, and $5 \mathrm{mM}$ HEPES; $\mathrm{pH}$ was adjusted to 7.3 using $\mathrm{NaOH}$. An equilibration period for dialysis was allowed to adequately clamp the cell currents. $I_{\mathrm{Na} \text {-Late }}$ was measured as the tetrodotoxin (TTX, $30 \mu \mathrm{M}$ )-sensitive portion of the current traces obtained when the voltage was ramped back to -100 $\mathrm{mV}(31)$.

The L-type $\mathrm{Ca}^{2+}$ current $\left(I_{\mathrm{Ca}-\mathrm{L}}\right)$ was measured as an inward current during depolarization from a holding potential of $-50 \mathrm{mV}$ to test potentials ranging from -40 to $+60 \mathrm{mV}$ in $10 \mathrm{mV}$ steps for $300 \mathrm{~ms}$ at a frequency of $0.1 \mathrm{~Hz}$ using a perforated patch clamp with amphotericin B. The micropipettes were filled with a solution containing $130 \mathrm{mM} \mathrm{CsCl,} 1 \mathrm{mM} \mathrm{MgCl}$, $5 \mathrm{mM} \mathrm{MgATP,}$ $10 \mathrm{mM}$ HEPES, $0.1 \mathrm{mM} \mathrm{NaGTP}$, and $5 \mathrm{mM} \mathrm{Na}_{2}$ phosphocreatine, which was titrated to a $\mathrm{pH}$ of 7.2 using $\mathrm{CsOH} . \mathrm{NaCl}$ and $\mathrm{KCl}$ in the external solution were replaced with tetraethylammonium chloride and $\mathrm{CsCl}$, respectively. Voltage-gated $\mathrm{Ca}^{2+}$ channel current was plotted on the I-V curve and the curve was fitted with the modified Boltzmann equation: $\mathrm{I}(V)=\left[\mathrm{G}_{\max } \times(\mathrm{V}-\right.$ $\left.\left.\mathrm{V}_{\text {rev }}\right)\right] /\left\{1+\mathrm{e}^{[(\mathrm{V} 1 / 2-\mathrm{V}) / \mathrm{k}]}\right\}$, where $\mathrm{I}(V)$ is the peak current density at the command potential $\mathrm{V}, \mathrm{G}_{\max }$ is the maximum conductance, $\mathrm{V}_{\text {rev }}$ is the reverse potential, $\mathrm{V}_{1 / 2}$ is the voltage at which halfmaximum $I_{\mathrm{Ca}-\mathrm{L}}$ is observed, and $k$ is the slope factor (26).

The $\mathrm{Na}^{+}-\mathrm{Ca}^{2+}$ exchanger (NCX) current was elicited by depolarizing pulses between -100 and $+100 \mathrm{mV}$ from a holding potential of $-40 \mathrm{mV}$ for $300 \mathrm{~ms}$ at a frequency of $0.1 \mathrm{~Hz}$. The amplitudes of the NCX current were measured as 10-mM nickelsensitive currents. The external solution consisted of $140 \mathrm{mM}$ $\mathrm{NaCl}, 2 \mathrm{mM} \mathrm{CaCl}, 1 \mathrm{mM} \mathrm{MgCl} 2,5 \mathrm{mM}$ HEPES, and $10 \mathrm{mM}$ glucose at $\mathrm{pH} 7.4$ and contained $10 \mu \mathrm{M}$ strophanthidin, $10 \mu \mathrm{M}$ nitrendipine, and $100 \mu \mathrm{M}$ niflumic acid. Micropipettes were filled with a solution containing $20 \mathrm{mM} \mathrm{NaCl}, 110 \mathrm{mM} \mathrm{CsCl}$, $0.4 \mathrm{mM} \mathrm{MgCl}_{2}, 1.75 \mathrm{mM} \mathrm{CaCl}_{2}, 20 \mathrm{mM} \mathrm{TEACl}, 5 \mathrm{mM}$ BAPTA, $5 \mathrm{mM}$ glucose, $5 \mathrm{mM} \mathrm{MgATP}$, and $10 \mathrm{mM}$ HEPES (at pH 7.25 adjusted using $\mathrm{CsOH}$ ).

The transient outward potassium $\left(\mathrm{K}^{+}\right)$current $\left(I_{\text {to }}\right)$ was studied with a double-pulse protocol. A 30-ms pre-pulse from -80 to $-40 \mathrm{mV}$ was used to inactivate the $\mathrm{Na}^{+}$channels, followed by a $300-\mathrm{ms}$ test pulse to $+60 \mathrm{mV}$ in $10-\mathrm{mV}$ steps at a frequency of $0.1 \mathrm{~Hz} \cdot \mathrm{CdCl}_{2}(200 \mu \mathrm{M})$ was added to the bath solution to inhibit the $I_{\mathrm{Ca}-\mathrm{L}}$. $I_{\text {to }}$ was measured as the difference between the peak outward current and steadystate current.

Rapid delayed rectifier $\mathrm{K}^{+}$current $\left(I_{\mathrm{Kr}-\text { tail }}\right)$ was measured as the outward peak tail current density following a 3-s pre-pulse from a holding potential of $-40 \mathrm{mV}$ to voltage between -40 and $+60 \mathrm{mV}$ in $10-\mathrm{mV}$ steps at a frequency of $0.1 \mathrm{~Hz}$ in the presence of chromanol 293B $(30 \mu \mathrm{M})$ and $\mathrm{CdCl}_{2}(200 \mu \mathrm{M})$ in the $\mathrm{Ca}^{2+}$-free normal Tyrode's solution. Micropipettes were filled with a solution containing $120 \mathrm{mM} \mathrm{KCl}, 5 \mathrm{mM} \mathrm{MgCl}_{2}, 0.36 \mathrm{mM}$ $\mathrm{CaCl}_{2}, 5 \mathrm{mM}$ EGTA, $5 \mathrm{mM}$ HEPES $5 \mathrm{mM}$ glucose, $5 \mathrm{mM} \mathrm{K} \mathbf{2}^{-}$ ATP, $5 \mathrm{mM} \mathrm{Na}_{2}$-CrP, and $0.25 \mathrm{mM} \mathrm{Na}-\mathrm{GTP}$ (at pH 7.2 adjusted using $\mathrm{KOH})$.

\section{Measurement of Intracellular $\mathbf{C a}^{2+}$ Transient}

Intracellular $\mathrm{Ca}^{2+}$ concentration $\left(\left[\mathrm{Ca}^{2+}\right]_{\mathrm{i}}\right)$ was recorded using a fluorometric ratio technique as previously described $(26,28)$. The control and FGF1 $(10 \mathrm{ng} / \mathrm{mL})$-treated PV and LA myocytes were loaded with fluorescent $\mathrm{Ca}^{2+}(10 \mu \mathrm{M})$ fluo-3/AM for $30 \mathrm{~min}$ at room temperature. Excess extracellular dye was removed by changing the bath solution, and intracellular hydrolysis of fluo$3 / \mathrm{AM}$ occurred at $35 \pm 1^{\circ} \mathrm{C}$ after $30 \mathrm{~min}$. Fluo-3 fluorescence was excited with a 488-nm line of an argon ion laser. The emission was recorded at $>515 \mathrm{~nm}$. The cells were repeatedly scanned at 2-ms intervals for a total duration of $6 \mathrm{~s}$. Fluorescence imaging 
A

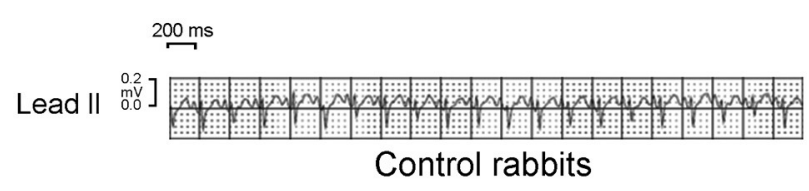

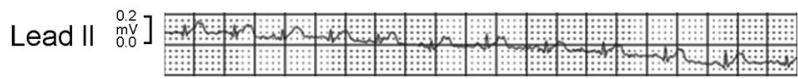

FGF1-treated rabbits

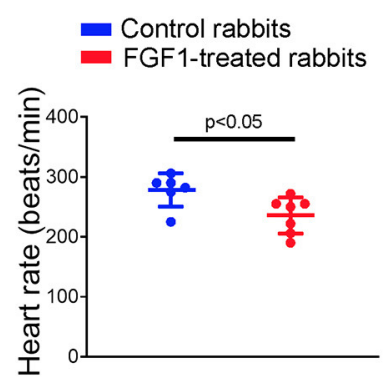

B
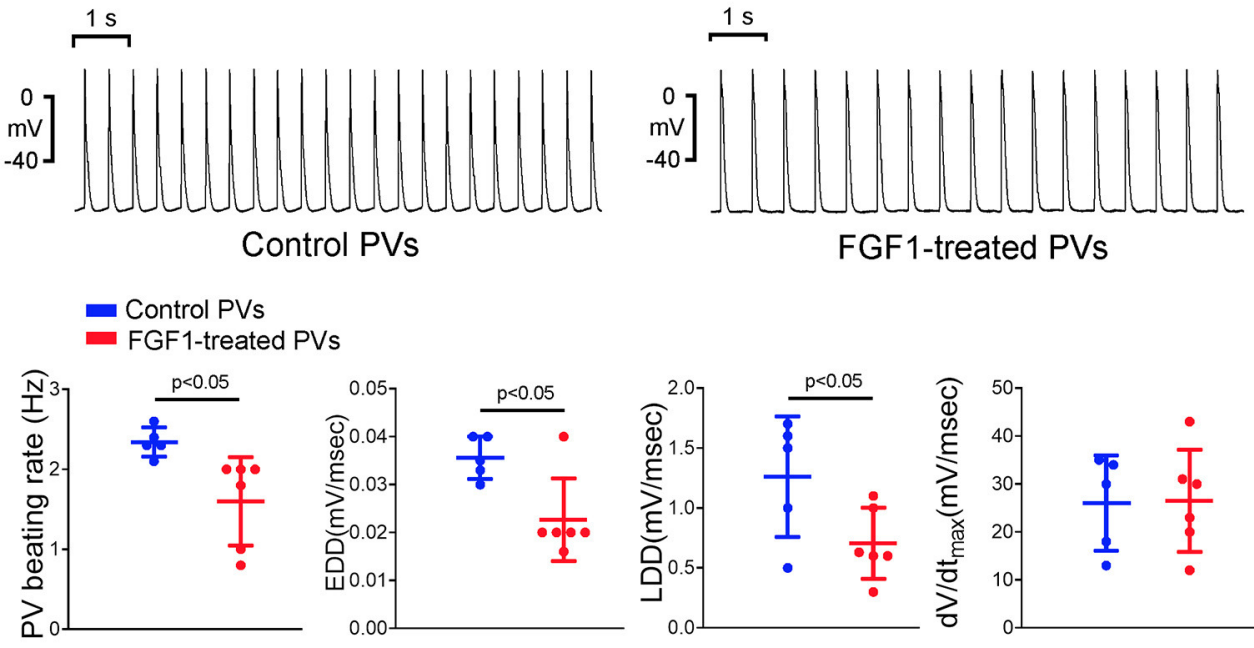

C
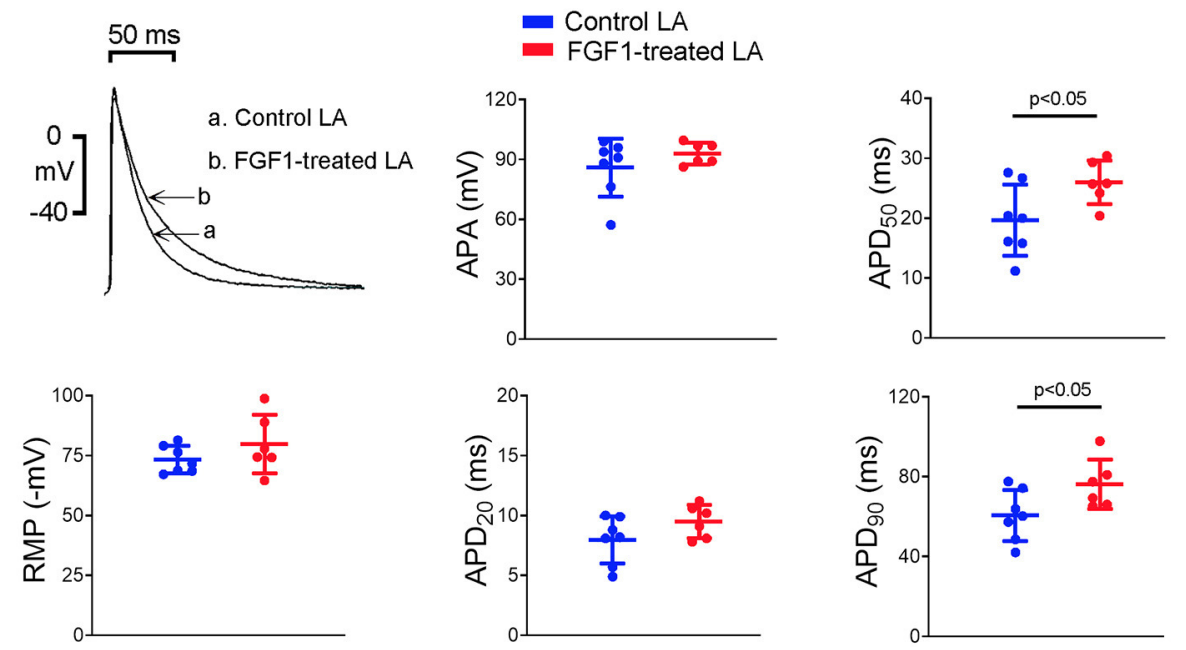

FIGURE 1 | Effects of fibroblast growth factor 1 (FGF1) on the electrocardiography (ECG) of rabbits and electrophysiological characteristics of pulmonary vein (PV) and left atrial (LA) tissues. (A) Control rabbits $(N=6)$ had a faster regular rhythm than that observed in FGF1 (3 $\mu \mathrm{g} / \mathrm{kg})$-treated rabbits $(N=6)$. (B) Tracings and scatter plots illustrated that PV tissues of FGF1 $(3 \mu \mathrm{g} / \mathrm{kg})$-treated rabbits $(N=6)$ had a slower spontaneous activities with a decreased early and late diastolic depolarization than that observed in control rabbits $(N=5)$. (C) Examples and scatter plots of the action potential (AP) morphology from $L A$ tissues under regular pacing $(2 \mathrm{~Hz})$ in the control $(N=7)$ and FGF1 $(3 \mu \mathrm{g} / \mathrm{kg})$-treated rabbits $(N=6)$. RMP indicates resting membrane potential, APA indicates AP amplitude, $A P D_{20}, \mathrm{APD}_{50}$, and $\mathrm{APD} 90$ indicate that AP duration at 20,50, and 90\% repolarization of the amplitude, respectively, EDD indicates early diastolic depolarization, LDD indicates late diastolic depolarization, $\mathrm{dV} / \mathrm{dt}_{\max }$ indicates maximum upstroke velocity. 
was performed using a laser scanning confocal microscope (Zeiss LSM 510, Carl Zeiss, Jena, Germany) and an inverted microscope (Axiovert 100).

Fluorescent signals were corrected for variations in dye concentrations by normalizing the fluorescence (represented by $\mathrm{F}$ ) against baseline fluorescence (F0) to obtain reliable information about transient $\left[\mathrm{Ca}^{2+}\right]_{\mathrm{i}}$ changes from baseline values, as (F-F0)/F0, and to exclude variations in the fluorescence intensity by different volumes of injected dye. The $\left[\mathrm{Ca}^{2+}\right]_{\mathrm{i}}$ transient was measured during a $2-\mathrm{Hz}$ field stimulation for $10 \mathrm{~ms}$ with square wave pulses that had two times the threshold strength.

\section{Cellular Reactive Oxygen Species \\ Measurement}

We used the CellROX green (Life Technologies, Grand Island, NY, USA) to assess cytosolic ROS production in the control and FGF1 (10 ng/mL)-treated PV and LA myocytes. Experiments

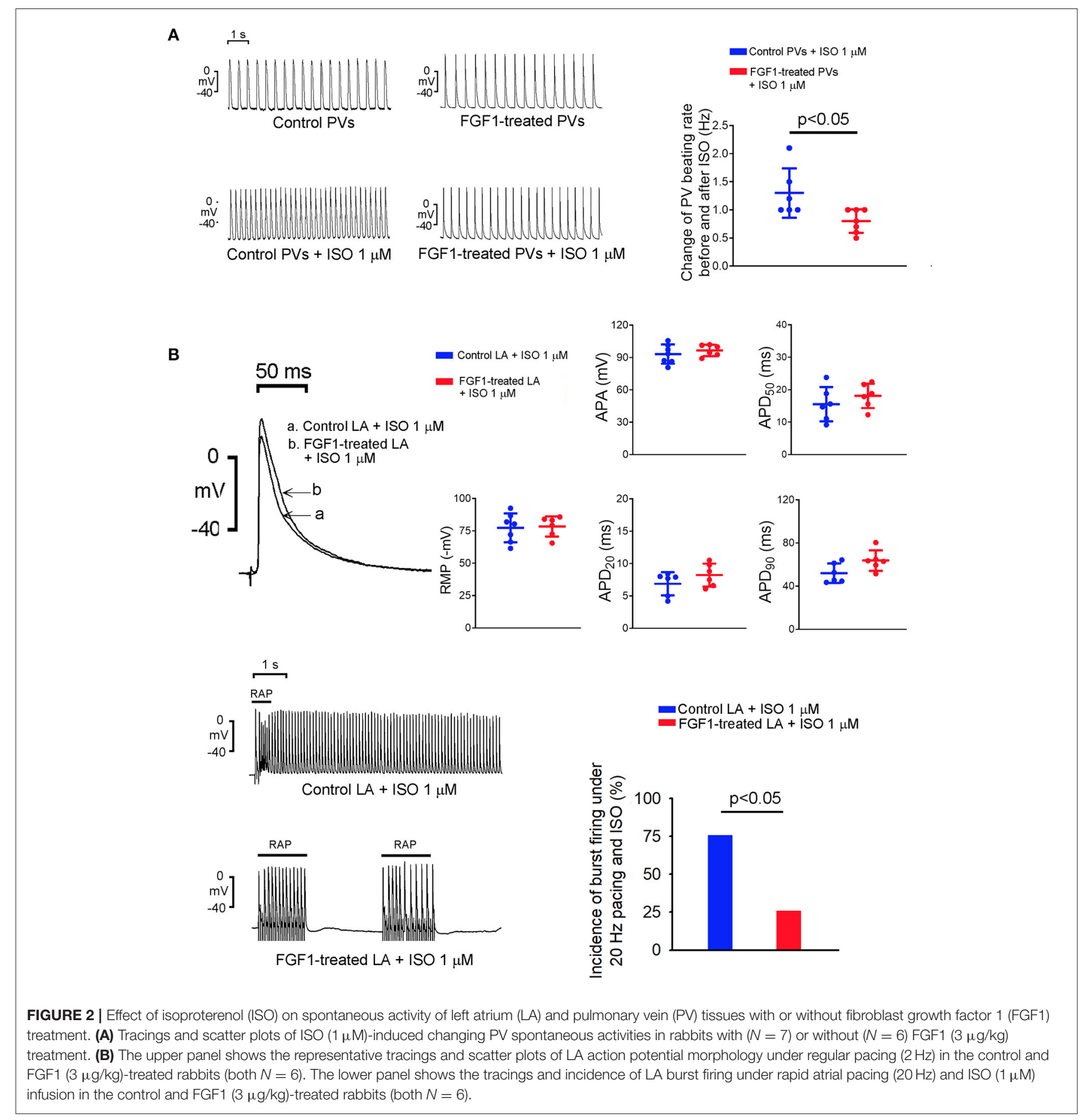


were also performed using a laser scanning confocal microscope (Zeiss LSM 510, Carl Zeiss) and an inverted microscope (Axiovert 100) with a $63 \times 1.25$ numerical aperture oil immersion objective as described previously (32). Cardiomyocytes were maintained in oxygenated normal Tyrode's solution: $137 \mathrm{mM}$ $\mathrm{NaCl}, 5.4 \mathrm{mM} \mathrm{KCl}, 1.8 \mathrm{mM} \mathrm{CaCl}_{2}, 0.5 \mathrm{mM} \mathrm{MgCl}_{2}, 10 \mathrm{mM}$ HEPES and $11 \mathrm{mM}$ glucose; with the $\mathrm{pH}$ adjusted to 7.4 by titrating with $1 \mathrm{~N} \mathrm{NaOH}$ ) supplemented with the appropriate fluorescent dye of $10 \mu \mathrm{M}$ CellROX green. CellROX green was excited at $488 \mathrm{~nm}$ and fluorescence signals were acquired at wavelengths of $>505 \mathrm{~nm}$ in the XY mode of the confocal system. Fluorescent images were analyzed using Image-Pro plus 6.0 and Sigmaplot 12.3 software (4).

The level of malondialdehyde (MDA) in control and FGF1 $(10 \mathrm{ng} / \mathrm{mL})$-treated PV and LA myocytes to detect lipid peroxidation were assessed by an ELISA kit, according to the manufacturer's guidelines and a colorimetric-fluorimetric method.

\section{Statistical Analysis}

All quantitative data are expressed as mean \pm standard deviation. The one-way analysis of variance (ANOVA) followed by Dunn's post-hoc test or the Wilcoxon rank-sum test was used to compare the differences between the control and FGF1-treated groups. Nominal variables were compared using Chi-squared analysis with Fisher's exact test. A $P<0.05$ was considered statistically significant.

\section{RESULTS}

\section{Effects of FGF1 on the Electrocardiography of Rabbits and the Electrophysiological Characteristics of PV and LA Tissues}

FGF1 (3 $\mu \mathrm{g} / \mathrm{kg})$-treated rabbits had a slower heart rate than that observed in control rabbits (Figure 1A). PV tissues of the FGF1 (3 $\mu \mathrm{g} / \mathrm{kg})$-treated rabbits had a slower beating rate than that of
A

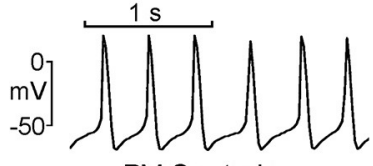

PV Control

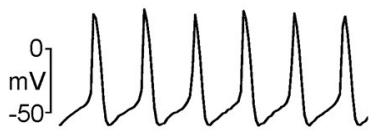

PV FGF-1 $1 \mathrm{ng} / \mathrm{mL}$

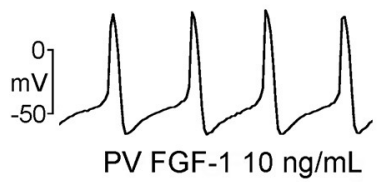

C

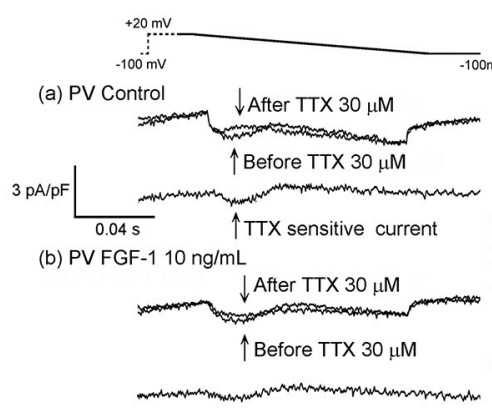

$\uparrow T T X$ sensitive current
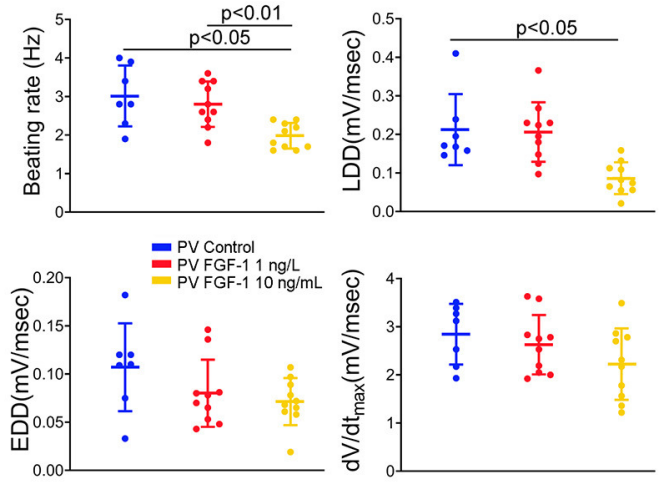

D
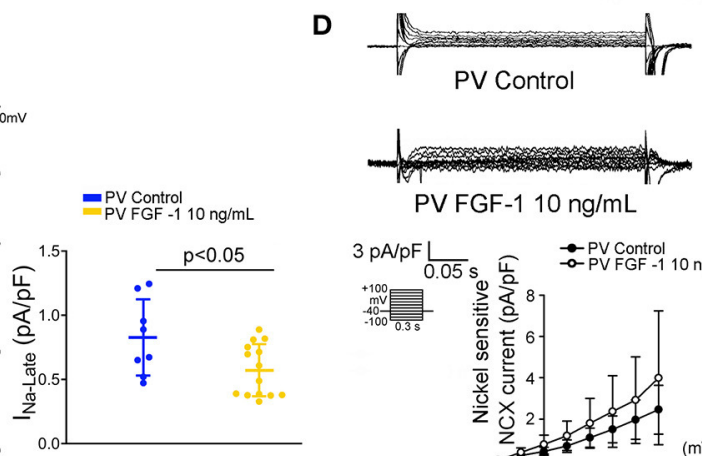

B
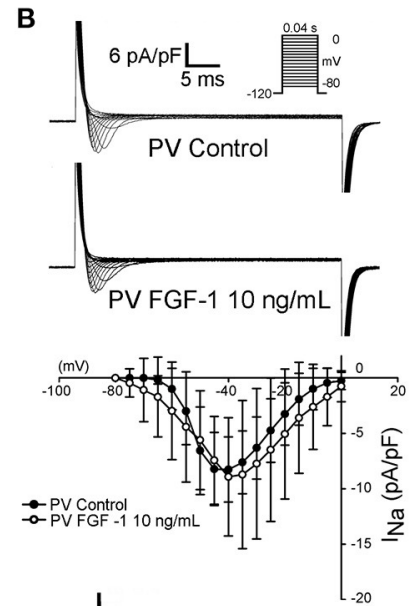

E
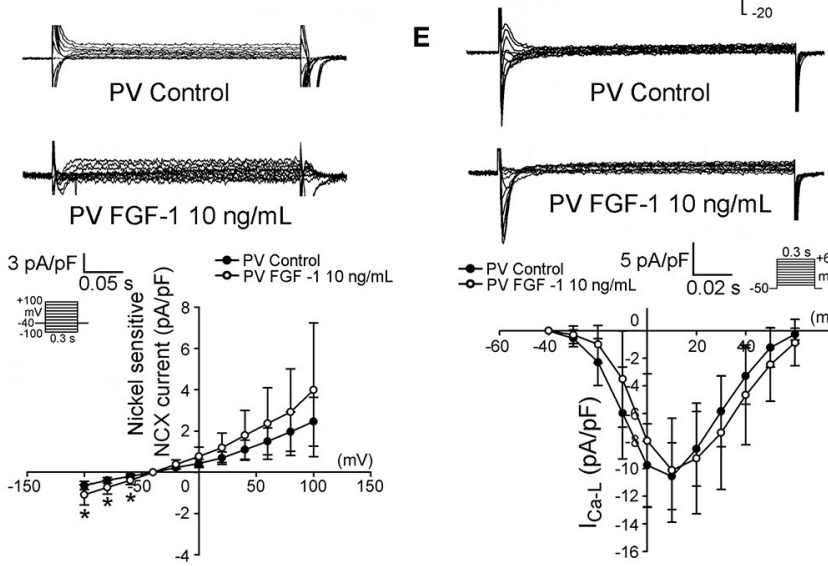
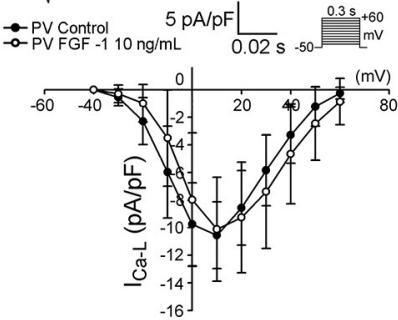

FIGURE 3 | Effect of fibroblast growth factor 1 (FGF1) on spontaneous activities, sodium $\left(\mathrm{Na}^{+}\right)$current $\left(/_{\mathrm{Na}}\right)$, late $\mathrm{Na}^{+}$current (/Na-Late), sodium-calcium exchanger $(\mathrm{NCX})$, and L-type calcium current $\left(l_{\mathrm{Ca}-\mathrm{L}}\right)$ of pulmonary vein (PV) myocytes. (A) Examples of current traces and scatter plots of beating rate in the control $(\mathrm{N}=7)$ and FGF1 (1 and $10 \mathrm{ng} / \mathrm{mL}$ )-treated PV myocytes (both $N=10$ ). (B) Examples of current traces and scatter plots of $/ \mathrm{Na}$ in the control $(N=8)$ and FGF1 (10 ng/mL)-treated PV myocytes $(N=9)$. (C) Examples of current traces and scatter plots of $/$ Na-Late in the control $(N=8)$ and FGF1 $(10 \mathrm{ng} / \mathrm{mL})$-treated PV myocytes $(N=14)$. (D) Examples of current traces and $I-V$ relationship of NCX in the control $(N=7)$ and FGF1 $(10 \mathrm{ng} / \mathrm{mL})$-treated PV myocytes $(N=9)$. (E) Examples of current traces and $I-V$ relationship of $\mathrm{I}_{\mathrm{Ca}-\mathrm{L}}$ in the control $(N=7)$ and FGF1 $(10 \mathrm{ng} / \mathrm{mL})$-treated PV myocytes (both $\left.N=9\right) .{ }^{*} P<0.05$. 
A
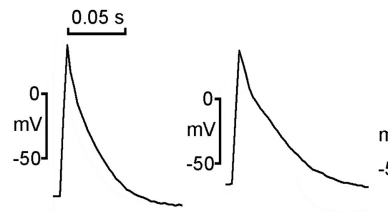

LA-Control

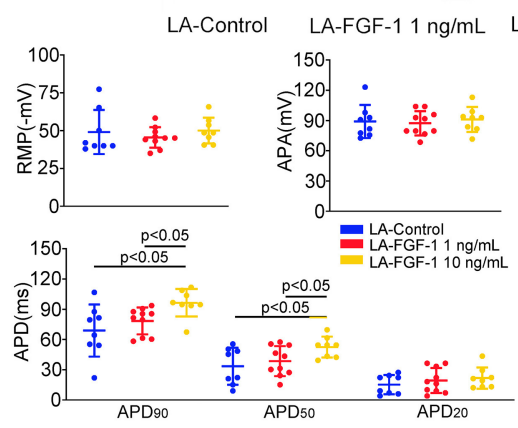

D

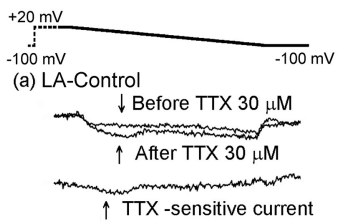

(b) LA-FGF-1 $10 \mathrm{ng} / \mathrm{mL}$

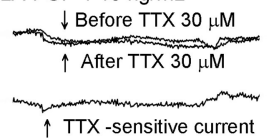

B

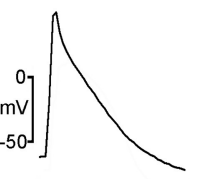

LA-FGF-1 $10 \mathrm{ng} / \mathrm{mL}$

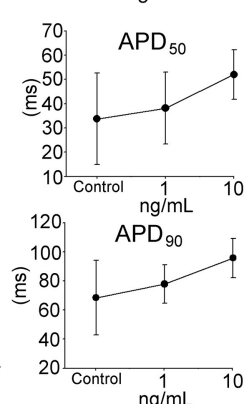

Control $\underset{n g / m L}{1} 10$

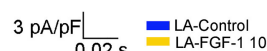

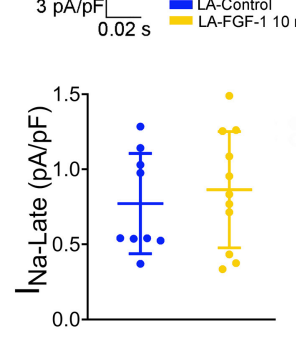

B
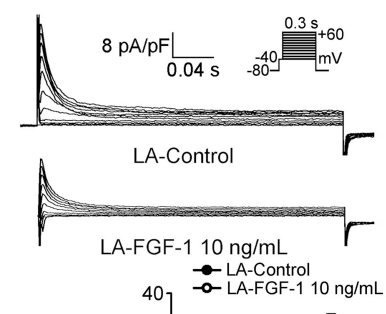
$\rightarrow-$ LA-Control
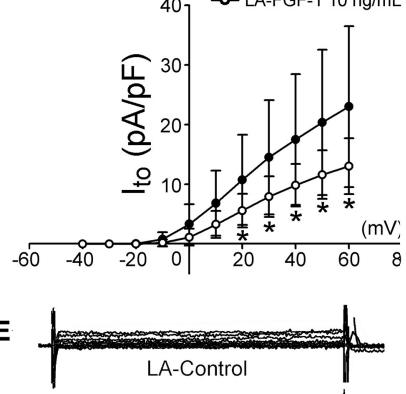

.

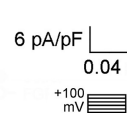

LA-F

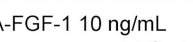

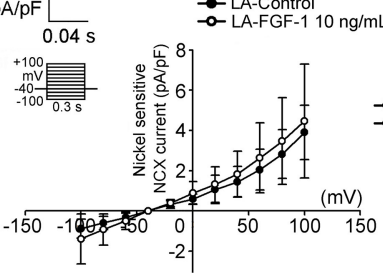

C
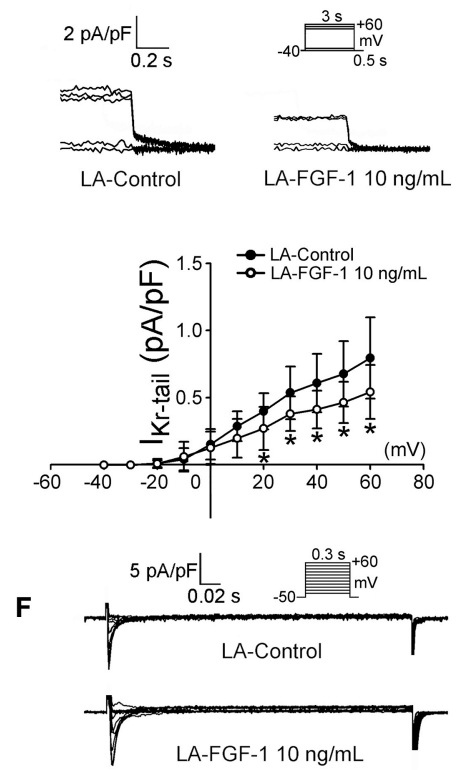

LA-FGF-1 $10 \mathrm{ng} / \mathrm{mL}$

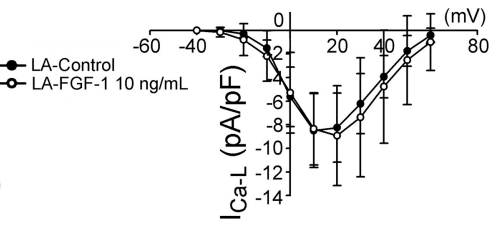

FIGURE 4 | Effect of fibroblast growth factor 1 (FGF1) on action potential morphology, transient outward potassium current (Ito) and rapid delayed rectifier potassium current $\left(I_{\mathrm{Kr} \text {-tail }}\right)$, late sodium current ( $\left.\mathrm{I}_{\mathrm{Na}-\mathrm{Late}}\right)$, sodium-calcium exchanger (NCX), and L-type calcium current $\left(\mathrm{I}_{\mathrm{Ca}-\mathrm{L}}\right)$ in left atrium $(\mathrm{LA})$ myocytes. $(\mathbf{A})$ Examples of current traces, scatter plots of electrophysiological characteristics and dose response curves on the control (N=8) and FGF1 (1 and 10 ng/mL)-treated LA myocytes ( $N=10$ and 8, respectively). (B) Examples of current traces and $I-V$ relationship of to $_{\text {o }}$ in the control $(N=9)$ and FGF1 (10 ng/mL)-treated LA myocytes ( $\left.N=10\right)$. (C) Examples of current traces and $I-V$ relationship of $I_{\text {Kr-tail }}$ in the control $(N=12)$ and FGF1 (10 ng/mL)-treated $L A$ myocytes $(N=10)$. (D) Examples of current traces and scatter plots of $I_{\mathrm{Na} \text {-Late }}$ in the control $(N=9)$ and FGF1 $(10 \mathrm{ng} / \mathrm{mL})$-treated LA myocytes $(N=11)$. (E) Examples of current traces and $I-V$ relationship of $N C X$ in the control and FGF1 $(10 \mathrm{ng} / \mathrm{mL})$-treated LA myocytes (both $N=6)$. (F) Examples of current traces and $I-V$ relationship of $I_{C a-L}$ in the control and FGF1

(10 ng/mL)-treated LA myocytes (both $N=10)$. ${ }^{\star} P<0.05$.

control rabbits. Compare to the AP of control rabbits, FGF1 (3 $\mu \mathrm{g} / \mathrm{kg}$ )-treated rabbits had a similar $\mathrm{dV} / \mathrm{dt}_{\max }$, but a reduced steepness of EDD and LDD of PV tissues (Figure 1B). Moreover, LA tissues of the FGF1 $(3 \mu \mathrm{g} / \mathrm{kg})$-treated rabbits had a longer $\mathrm{APD}_{50}$ and $\mathrm{APD}_{90}$ than those in control rabbits (Figure 1C).

As shown in Figure 2A, isoproterenol $(1 \mu \mathrm{M})$-treated PV tissues in the FGF1 $(3 \mu \mathrm{g} / \mathrm{kg})$-treated rabbits showed less changes in the increased beating rate than those of tissues in control rabbits. On an isoproterenol $(1 \mu \mathrm{M})$ infusion, there were no differences in RMP, $\mathrm{APA}, \mathrm{APD}_{20}, \mathrm{APD}_{50}$, and $\mathrm{APD}_{90}$ in LA tissues between the FGF1 ( $3 \mu \mathrm{g} / \mathrm{kg})$-treated and control rabbits (Figure 2B). Furthermore, the incidence of tachypacing $(20 \mathrm{~Hz})$ induced burst firing in isoproterenol $(1 \mu \mathrm{M})$-treated LA tissues was lower in the FGF1 $(3 \mu \mathrm{g} / \mathrm{kg})$-treated rabbits than in the tissues of control rabbits.

\section{Effects of FGF1 on the Electrophysiological Characteristics of PV and LA Myocytes}

FGF1 (10 ng/mL)-treated PV myocytes had a slower spontaneous beating rate than that observed in control and
FGF1 (1 ng/mL)-treated PV myocytes. Compared to control PV myocytes, FGF1 (3 $\mu \mathrm{g} / \mathrm{kg}$ )-treated PV myocytes had a similar $\mathrm{dV} / \mathrm{dt}_{\max }$ and $\mathrm{EDD}$, but a reduced steepness of LDD (Figure 3A). FGF1 (10 ng/mL)-treated PV myocytes had a smaller $\mathrm{I}_{\mathrm{Na}-\mathrm{L}}$ and larger forward mode of NCX than those observed in control myocytes (Figures 3C,D). FGF1 $(10 \mathrm{ng} / \mathrm{mL})$-treated PV and control myocytes had similar $I_{\mathrm{Na}}$ and $I_{\mathrm{Ca}-\mathrm{L}}$ (Figures 3B,E). The voltage-dependence of $I_{\mathrm{Ca}-\mathrm{L}}$ activation was not different between FGF1 $(1 \mathrm{ng} / \mathrm{mL})$-treated and control PV myocytes with $\mathrm{V}_{1 / 2}$ value of $-6.77 \pm 8.64 \mathrm{mV}$ and $-11.07 \pm 7.78 \mathrm{mV}$ in FGF1 (1 ng/mL)-treated and control PV myocytes, respectively.

As shown in Figure 4A, FGF1 $(10 \mathrm{ng} / \mathrm{mL})$-treated LA myocytes had longer $\mathrm{APD}_{50}$ and $\mathrm{APD}_{90}$ than those of the control and FGF1 (1 ng/mL)-treated LA myocytes. FGF1 (10 ng/mL)treated LA myocytes had smaller $I_{\text {to }}$ and $I_{\mathrm{Kr} \text {-tail }}$ than those of control myocytes (Figures 4B,C). FGF1 (10 ng/mL)-treated LA and control myocytes had similar $\mathrm{I}_{\mathrm{Na}-\mathrm{L}}, \mathrm{NCX}$, and $I_{\mathrm{Ca}-\mathrm{L}}$ (Figures 4D-F). The voltage-dependence of $I_{\mathrm{Ca}-\mathrm{L}}$ activation was not different between FGF1 (1 ng/mL)-treated and control LA myocytes with $\mathrm{V}_{1 / 2}$ value of $-4.44 \pm 7.06 \mathrm{mV}$ and 

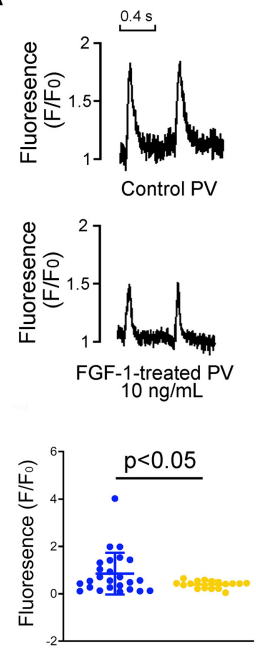
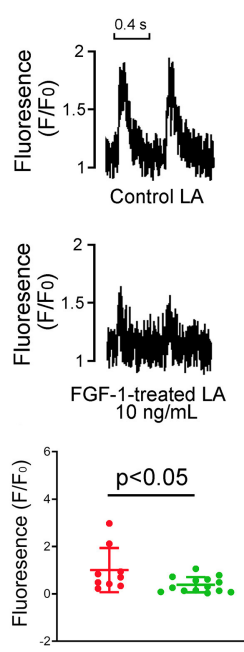
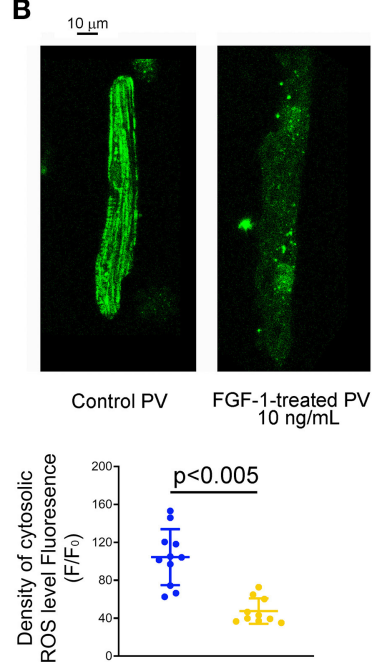

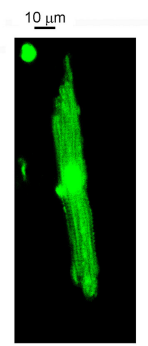

Control LA

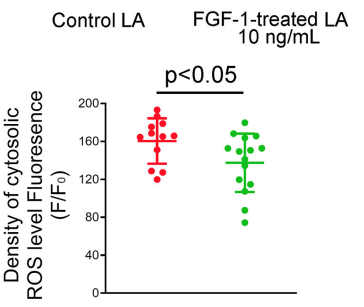

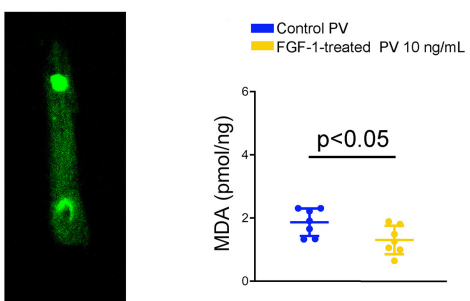
Control LA

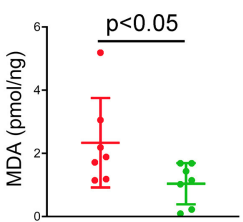

FIGURE 5 | Effect of fibroblast growth factor 1 (FGF1) on intracellular calcium ( $\mathrm{Ca}^{2+}$ ) homeostasis, reactive oxygen species (ROS) and cytosol malondialdehyde (MDA) in pulmonary vein (PV) and left atrium (LA) myocytes. (A) Examples of tracings and scatter plots of $\mathrm{Ca}^{2+}$ transients in the control and FGF1 (10 ng/mL)-treated PV ( $\mathrm{N}=$ 25 and 17, respectively), and LA ( $N=9$ and 14, respectively), myocytes. (B) Examples and scatter plots of cellular levels of ROS in the control and FGF1 (10 ng/mL)-treated PV ( $N=11$ and 10, respectively), and LA ( $N=12$ and 15, respectively), myocytes. (C) Scatter plots of cytosol MDA in control and FGF1 (10 $\mathrm{ng} / \mathrm{mL})$-treated PV (each $N=7$ ) and LA (each $N=7$ ) tissues.

$-0.90 \pm 3.92 \mathrm{mV}$ in FGF1 ( $1 \mathrm{ng} / \mathrm{mL})$-treated and control LA myocytes, respectively.

\section{Effects of FGF1 on $\mathrm{Ca}^{2+}$ Transient and Oxidative Stress of PV and LA Myocytes}

FGF1 (10 ng/mL)-treated PV and LA myocytes had smaller $\mathrm{Ca}^{2+}$ transients than those of control PV and LA myocytes, respectively (Figure 5A). In addition, FGF1 (10 ng/mL)-treated PV and LA myocytes had less cellular oxidative stress than those of control PV and LA myocytes, respectively (Figure 5B). As shown in Figure 5C, PV and LA cells in FGF1 $(3 \mu \mathrm{g} / \mathrm{kg})$-treated rabbits had less MDA compared with cells in the control rabbits.

\section{Effects of PKC Inhibitor on the lonic Currents of FGF1-Treated PV and LA Myocytes}

As shown in Figures 6A,B, $\varepsilon V 1-2(200 \mathrm{nM})$ abolished the inhibitory effect of FGF1 $(10 \mathrm{ng} / \mathrm{mL})$ on the $I_{\text {to }}$ and $I_{\mathrm{Kr}-\text { tail }}$ of LA myocytes. Moreover, $\varepsilon V 1-2(200 \mathrm{nM})$ abolished the inhibitory effect of FGF1 $(10 \mathrm{ng} / \mathrm{mL})$ on the $\mathrm{I}_{\mathrm{Na}-\mathrm{L}}$ of $\mathrm{PV}$ myocytes (Figure 6C).

\section{DISCUSSION}

In the present study, we have demonstrated that FGF1, a potential novel therapeutic agent for treating metabolic conditions, modulates electrophysiological characteristics and possess antiredox activity in rabbit hearts. To the best of our knowledge, this is the first study to demonstrate that FGF1 suppresses PV spontaneous activity and isoproterenol-induced LA burst firing.
Moreover, FGF1 prolongs APD of the LA. $I_{\mathrm{Na}-\mathrm{L}}$ determines the rate of spontaneous depolarization in sinoatrial node cells and contributes to cardiac automaticity (33). The effect of FGF1 on reducing the intrinsic rabbit heart rate was considered to reflect $I_{\mathrm{Na}-\mathrm{L}}$ inhibition. $I_{\mathrm{Na}-\mathrm{L}}$ can contribute to the diastolic depolarization of PV myocytes and the inhibition of this current suppresses PV diastolic depolarization and spontaneous APs (34). $I_{\mathrm{Na}-\mathrm{L}}$ plays an important role in $\mathrm{PV}$ arrhythmogenesis and $\mathrm{AF}$ occurrence $(4,35)$. Activation of $\mathrm{I}_{\mathrm{Na}-\mathrm{L}}$ enhances the genesis of triggered activity due to $\mathrm{Ca}^{2+}$ overload. In the present study, FGF1 decreased the $I_{\mathrm{Na}-\mathrm{L}}$ and increased the forward mode of NCX in PV myocytes. NCX operated dominantly in the forward mode increased $\mathrm{Ca}^{2+}$ efflux, which was considered a compensatory effect for decreasing intracellular $\mathrm{Na}^{+}$via FGF1-related $I_{\mathrm{Na}-\mathrm{L}}$ inhibition in PV myocytes. Moreover, FGFtreated PVs displayed suppression of burst firing induced by isoproterenol. Isoproterenol, an adrenergic agonist, promotes an increase in pacemaker activity and abnormal automatism through the accumulation of $\left[\mathrm{Ca}^{2+}\right]_{\mathrm{I}}$ (36). $\mathrm{Ca}^{2+}$ dysregulation may induce AF via the electrical remodeling of PVs and the LA (16, 17). Moreover, our previous study found that hydrogen peroxide enhances oxidative stress-induced PV and atrial arrhythmia via the modification of electrophysiological characteristics and $\mathrm{Ca}^{2+}$ or $\mathrm{K}^{+}$currents $(15,37)$. FGF1 binding to activate all FGFRs in various tissues might regulate intracellular $\mathrm{Ca}^{2+}$ homeostasis leading to a protective role in metabolic disorders $(38,39)$. FGF1 also displays favorable effects on maintaining myocardial integrity and preventing cardiac dysfunction in post-myocardial infarction (40). Our study showed that FGF1-treated PV and LA cells have a smaller $\mathrm{Ca}^{2+}$ transients and less oxidative stress than those of control 

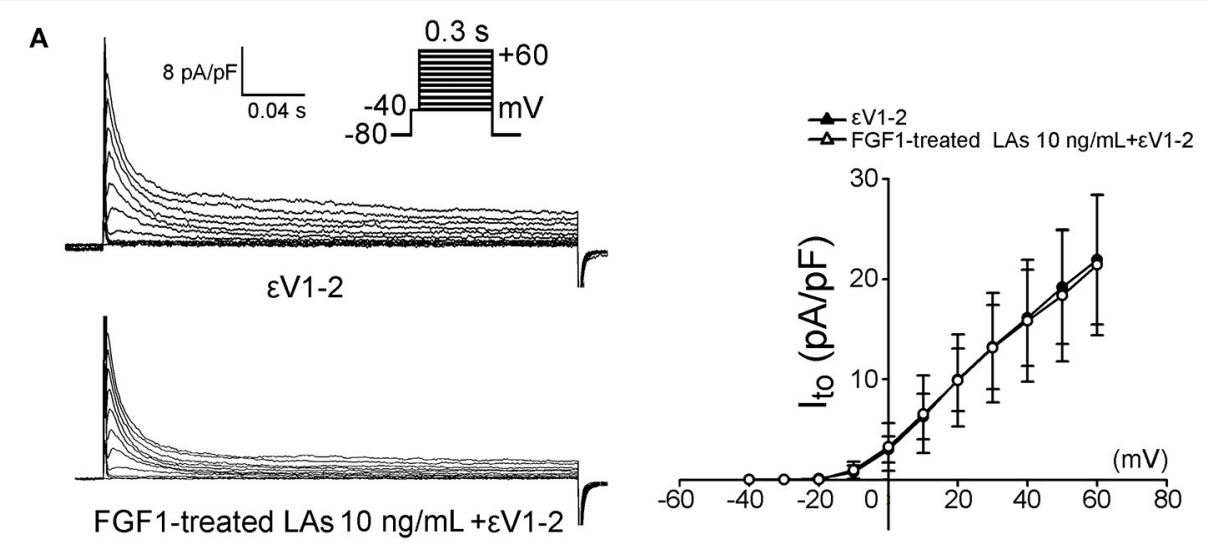

B
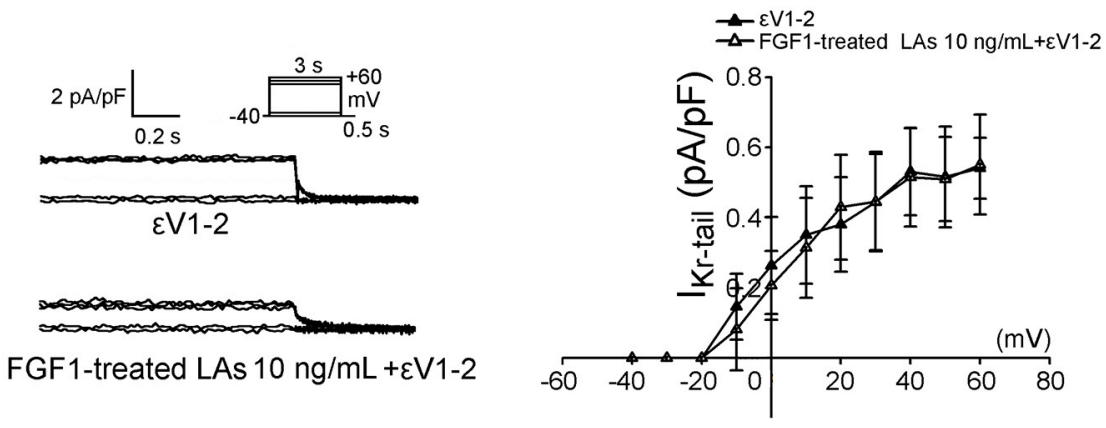

C
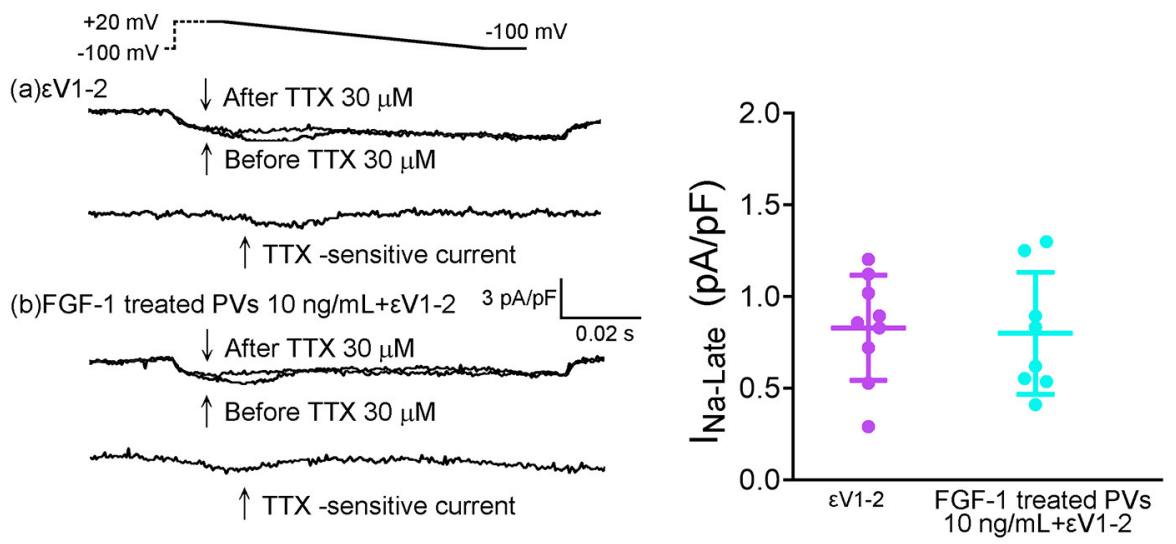

FIGURE 6 | Effect of protein kinase C epsilon inhibitor $(\varepsilon \vee 1-2)$ on transient outward potassium current $\left(I_{\text {to }}\right)$ and rapid delayed rectifier potassium current $\left(I_{\text {Kr-tail }}\right)$ in FGF1-treated left atrial (LA) myocytes, and on late sodium current ( $\left.l_{\text {Na-Late }}\right)$ in FGF1-treated pulmonary vein (PV) myocytes. (A) Examples of current traces and $l-V$ relationship of $I_{\text {to }}$ in FGF1 $(10 \mathrm{ng} / \mathrm{mL})$-treated LA myocytes with or without $\varepsilon V 1-2(200 \mathrm{nM})($ each $N=7)$. (B) Examples of current traces and $I-V$ relationship of $I_{\mathrm{Kr} \text {-tail }}$ in FGF1 (10 ng/mL)-treated LA myocytes with $(N=8)$ or without $(N=9) \varepsilon V 1-2(200 \mathrm{nM})$. (C) Examples of current traces and average data of $/$ Na-Late in FGF1 (10 ng/mL)-treated PV myocytes with $(N=8)$ or without $(N=9) \varepsilon \vee 1-2(200 \mathrm{nM})$.

PV and LA cells. These results suggest that FGF1 may change the electrophysiological characteristics of PV and LA through its effects on $\mathrm{Ca}^{2+}$ homeostasis or ROS $(4,41)$. However, our study model was restricted to normal physiological conditions, and more experiments are required to understand whether FGF1 will have any antiarrhythmic effect under more complex pathological conditions (such as $\mathrm{Ca}^{2+}$ overload, oxidative stress, or ischemia).

APD shortening is a hallmark of AF-related electrical remodeling, likely contributing to $\mathrm{AF}$ maintenance and progression (42). The LA plays a critical role in AF genesis when the APD is shortened in the LA by oxidative stress or under 
ischemic conditions (43). Gain-of-function mutations in channel subunits generating $I_{\text {to }}$ and $I_{\mathrm{Kr}}$ are associated with familial AF (44). Increased $I_{\text {to }}$ and $I_{\mathrm{Kr}}$ decrease the APD and effective refractory period, thereby increasing reentry. Chauhan-Patel et al. demonstrated that long-term exposure of FGF1 in embryonic myocytes decreases $\mathrm{K}^{+}$current density (45). In the present study, smaller $I_{\text {to }}$ and $I_{\mathrm{Kr}}$ caused the prolongation of the APD in FGF1-treated LA myocytes, which may reduce micro-reentry arrhythmogenesis (46). Our previous study demonstrated that the enhancement of $I_{\mathrm{Na}-\mathrm{L}}$ increases PV arrhythmogenesis (35), and selective $I_{\mathrm{Na}-\mathrm{L}}$ inhibition suppresses the PV triggers that initiate $\operatorname{AF}(35,47)$. $I_{\mathrm{Na}-\mathrm{L}}$ inhibition by FGF1 participates in suppressing LA arrhythmogenesis.

PKC is an important enzyme involved in myocardial ischemia/reperfusion (48). Our previous study revealed that FGF23, a FGF family member related to chronic kidney diseaseinduced AF, increases PV arrhythmogenesis due to $\mathrm{Na}^{+}$and $\mathrm{Ca}^{2+}$ dysregulation and mitochondrial ROS genesis via the activation of PKC signaling (4). In contrast, FGF1 reduced intracellular $\mathrm{Ca}^{2+}$ transients and oxidative stress; in addition, the effects of FGF1 on ionic currents could be blocked by PKC inhibitor in our present study. FGF1 is positively correlated with $\mathrm{PKC} \varepsilon$ expression in cardiogenesis (49). Activation of PKC negatively regulates $I_{\text {to }}$ and $I_{\mathrm{Kr}}$ in cardiomyocytes $(50,51)$. Moreover, PKC $\varepsilon$ activation induces the synthesis of NOS-derived nitric oxide and regulates cardiac intracellular $\mathrm{Na}^{+}$and $\mathrm{Ca}^{2+}$, which plays an important role in protecting the heart against $\mathrm{Na}^{+}$ and $\mathrm{Ca}^{2+}$ overload (52). It is speculated that FGF1 may decrease ROS levels and modulate PKC activity that may change PV and LA electrophysiological characteristics $(48,53)$.

\section{CONCLUSION}

In this study, we found that FGF1 can modulate PV and LA electrophysiological characteristics and $\mathrm{Ca}^{2+}$ homeostasis through the suppression of oxidative stress-induced PKC activation.

\section{REFERENCES}

1. Itoh N, Ohta H. Pathophysiological roles of FGF signaling in the heart. Front Physiol. (2013) 4:247. doi: 10.3389/fphys.2013.00247

2. Cuevas P, Reimers D, Carceller F, Martinez-Coso V, Redondo-Horcajo M, Saenz de Tejada I, et al. Fibroblast growth factor-1 prevents myocardial apoptosis triggered by ischemia reperfusion injury. Eur J Med Res. (1997) 2:465-8.

3. Htun P, Ito WD, Hoefer IE, Schaper J, Schaper W. Intramyocardial infusion of FGF-1 mimics ischemic preconditioning in pig myocardium. J Mol Cell Cardiol. (1998) 30:867-77. doi: 10.1006/jmcc.1998.0654

4. Huang SY, Chen YC, Kao YH, Hsieh MH, Lin YK, Chung CC, et al. Fibroblast growth factor 23 dysregulates late sodium current and calcium homeostasis with enhanced arrhythmogenesis in pulmonary vein cardiomyocytes. Oncotarget. (2016) 7:69231-42. doi: 10.18632/oncotarget.12470

5. Kao YH, Chen YC, Lin YK, Shiu RJ, Chao TF, Chen SA, et al. FGF-23 dysregulates calcium homeostasis and electrophysiological properties in HL-1 atrial cells. Eur J Clin Invest. (2014) 44:795-801. doi: 10.1111/eci.12296

6. Palmen M, Daemen MJ, De Windt LJ, Willems J, Dassen WR, Heeneman S, et al. Fibroblast growth factor-1 improves cardiac functional recovery and

\section{DATA AVAILABILITY STATEMENT}

The raw data supporting the conclusions of this article will be made available by the authors, without undue reservation.

\section{ETHICS STATEMENT}

The animal study was reviewed and approved by National Defense Medical Center Institutional Animal Care and Use Committee. Written informed consent was obtained from the owners for the participation of their animals in this study.

\section{AUTHOR CONTRIBUTIONS}

Y-YL and S-YH conducted experiments, analyzed data, and wrote the manuscript. Y-CC and Y-HK conducted experiments. Y-KL and $\mathrm{SH}$ contributed to the analysis and interpretation of the data. C-CC analyzed data and revised the manuscript. S-AC and Y-JC conceived and designed the study, revised the manuscript, and gave final approval. All authors have read and approved the final manuscript.

\section{FUNDING}

This work was supported by grants from the Ministry of Science and Technology (MOST108-2314-B-281-007-MY3, MOST109-2314-B-038-124-MY3, MOST109-2314-B-016-045, MOST109-2314-B-016-001-MY2, MOST110-2314-B-038-107MY3, and MOST110-2314-B-016-037-MY3), Taipei Medical University-Wan Fang Hospital (106-swf-10, 107-wf-swf-02, 107-wf-swf-07, 107-wf-eva-13, 108-wf-eva-06, 108-wf-swf-01, 108-wf-swf-06, 109-wf-eva-04, 109-wf-eva-18, and 109-wfswf-09), the Chi-Mei Medical Center (105CM-TMU-13, 106CM-TMU-08, 108CM-TMU-05, and 110CM-TMU-11), Ministry of National Defense-Medical Affairs Bureau (MNDMAB-D-111105), and the Foundation for the Development of Internal Medicine in Okinawa (2-02-005).

enhances cell survival after ischemia and reperfusion: a fibroblast growth factor receptor, protein kinase $\mathrm{C}$, and tyrosine kinase-dependent mechanism. J Am Coll Cardiol. (2004) 44:1113-23. doi: 10.1016/j.jacc.2004.05.067

7. Kannel WB, Wolf PA, Benjamin EJ, Levy D. Prevalence, incidence, prognosis, and predisposing conditions for atrial fibrillation: population-based estimates. Am J Cardiol. (1998) 82:2N-9. doi: 10.1016/S0002-9149(98)00583-9

8. Chen SA, Hsieh MH, Tai CT, Tsai CF, Prakash VS, Yu WC, et al. Initiation of atrial fibrillation by ectopic beats originating from the pulmonary veins: electrophysiological characteristics, pharmacological responses, and effects of radiofrequency ablation. Circulation. (1999) 100:1879-86. doi: 10.1161/01.CIR.100.18.1879

9. Chen YC, Pan NH, Cheng CC, Higa S, Chen YJ, Chen SA. Heterogeneous expression of potassium currents and pacemaker currents potentially regulates arrhythmogenesis of pulmonary vein cardiomyocytes. J Cardiovasc Electrophysiol. (2009) 20:1039-45. doi: 10.1111/j.1540-8167.2009.01480.x

10. Lo LW, Tai CT, Lin YJ, Chang SL, Wongcharoen W, Chang SH, et al. Progressive remodeling of the atrial substrate-a novel finding from consecutive voltage mapping in patients with recurrence of atrial fibrillation after catheter ablation. J Cardiovasc Electrophysiol. (2007) 18:25865. doi: 10.1111/j.1540-8167.2007.00719.x 
11. Szebenyi G, Fallon JF. Fibroblast growth factors as multifunctional signaling factors. Int Rev Cytol. (1999) 185:45106. doi: 10.1016/S0074-7696(08)60149-7

12. Kranenburg AR, De Boer WI, Van Krieken JH, Mooi WJ, Walters JE, Saxena PR, et al. Enhanced expression of fibroblast growth factors and receptor FGFR-1 during vascular remodeling in chronic obstructive pulmonary disease. Am J Respir Cell Mol Biol. (2002) 27:517-25. doi: 10.1165/rcmb.4474

13. Li XK, Lin ZF, Li Y, Hu S, Tan Y, Huang Z, et al. Cardiovascular protection of nonmitogenic human acidic fibroblast growth factor from oxidative damage in vitro and in vivo. Cardiovasc Pathol. (2007) 16:8591. doi: 10.1016/j.carpath.2006.11.004

14. Lin YK, Lin FZ, Chen YC, Cheng CC, Lin CI, Chen YJ, et al. Oxidative stress on pulmonary vein and left atrium arrhythmogenesis. Circ J. (2010) 74:1547-56. doi: 10.1253/circj.CJ-09-0999

15. Huang SY, Lu YY, Chen YC, Chen WT, Lin YK, Chen SA, et al. Hydrogen peroxide modulates electrophysiological characteristics of left atrial myocytes. Acta Cardiol Sin. (2014) 30:38-45.

16. Lo LW, Chen YC, Chen YJ, Wongcharoen W, Lin CI, Chen SA. Calmodulin kinase II inhibition prevents arrhythmic activity induced by alpha and beta adrenergic agonists in rabbit pulmonary veins. Eur J Pharmacol. (2007) 571:197-208. doi: 10.1016/j.ejphar.2007.05.066

17. Suenari K, Chen YC, Kao YH, Cheng CC, Lin YK, Chen YJ, et al. Discrepant electrophysiological characteristics and calcium homeostasis of left atrial anterior and posterior myocytes. Basic Res Cardiol. (2011) 106:6574. doi: 10.1007/s00395-010-0132-1

18. Padua RR, Merle PL, Doble BW, Yu CH, Zahradka P, Pierce GN, et al. FGF-2-induced negative inotropism and cardioprotection are inhibited by chelerythrine: involvement of sarcolemmal calcium-independent protein kinase C. J Mol Cell Cardiol. (1998) 30:2695-709. doi: 10.1006/jmcc.1998.0832

19. Tokola H, Salo K, Vuolteenaho O, Ruskoaho H. Basal and acidic fibroblast growth factor-induced atrial natriuretic peptide gene expression and secretion is inhibited by staurosporine. Eur J Pharmacol. (1994) 267:195206. doi: 10.1016/0922-4106(94)90171-6

20. Rockman HA, Ross RS, Harris AN, Knowlton KU, Steinhelper ME, Field LJ, et al. Segregation of atrial-specific and inducible expression of an atrial natriuretic factor transgene in an in vivo murine model of cardiac hypertrophy. Proc Natl Acad Sci USA. (1991) 88:827781. doi: 10.1073/pnas.88.18.8277

21. Lee TI, Kao YH, Chen YC, Pan NH, Lin YK, Chen YJ. Cardiac peroxisomeproliferator-activated receptor expression in hypertension co-existing with diabetes. Clin Sci (Lond). (2011) 121:305-12. doi: 10.1042/CS20100529

22. Huang SY, Chen YC, Kao YH, Hsieh MH, Chen YA, Chen WP, et al. Renal failure induces atrial arrhythmogenesis from discrepant electrophysiological remodeling and calcium regulation in pulmonary veins, sinoatrial node, and atria. Int J Cardiol. (2016) 202:846-57. doi: 10.1016/j.ijcard.2015.10.004

23. Chang SL, Chen YC, Chen YJ, Wangcharoen W, Lee SH, Lin CI, et al. Mechanoelectrical feedback regulates the arrhythmogenic activity of pulmonary veins. Heart. (2007) 93:82-8. doi: 10.1136/hrt.2006.089359

24. Wongcharoen W, Chen YC, Chen YJ, Chang CM, Yeh HI, Lin CI, et al. Effects of a $\mathrm{Na}+/ \mathrm{Ca}^{2+}$ exchanger inhibitor on pulmonary vein electrical activity and ouabain-induced arrhythmogenicity. Cardiovasc Res. (2006) 70:497508. doi: 10.1016/j.cardiores.2006.02.026

25. Chen YJ, Chen SA, Chang MS, Lin CI. Arrhythmogenic activity of cardiac muscle in pulmonary veins of the dog: implication for the genesis of atrial fibrillation. Cardiovasc Res. (2000) 48:265-73. doi: 10.1016/S0008-6363(00)00179-6

26. Lu YY, Chung FP, Chen YC, Tsai CF, Kao YH, Chao TF, et al. Distinctive electrophysiological characteristics of right ventricular out-flow tract cardiomyocytes. J Cell Mol Med. (2014) 18:1540-8. doi: 10.1111/jcmm.12329

27. Huang JH, Chen YC, Lu YY, Lin YK, Chen SA, Chen YJ. Arginine vasopressin modulates electrical activity and calcium homeostasis in pulmonary vein cardiomyocytes. J Biomed Sci. (2019) 26:71. doi: 10.1186/s12929-0190564-3

28. Huang SY, Chen YC, Kao YH, Hsieh MH, Lin YK, Chen SA, et al. Redox and activation of protein kinase a dysregulates calcium homeostasis in pulmonary vein cardiomyocytes of chronic kidney disease. J Am Heart Assoc. (2017) 6:e005701. doi: 10.1161/JAHA.117.005701
29. Lin YK, Chen YC, Huang JH, Lin YJ, Huang SS, Chen SA, et al. Leptin modulates electrophysiological characteristics and isoproterenolinduced arrhythmogenesis in atrial myocytes. J Biomed Sci. (2013) 20:94. doi: 10.1186/1423-0127-20-94

30. Chen YC, Kao YH, Huang CF, Cheng CC, Chen YJ, Chen SA. Heat stress responses modulate calcium regulations and electrophysiological characteristics in atrial myocytes. J Mol Cell Cardiol. (2010) 48:7818. doi: $10.1016 /$ j.yjmcc.2009.08.006

31. Orth PM, Hesketh JC, Mak CK, Yang Y, Lin S, Beatch GN, et al. RSD1235 blocks late $\mathrm{INa}$ and suppresses early afterdepolarizations and torsades de pointes induced by class III agents. Cardiovasc Res. (2006) 70:48696. doi: 10.1016/j.cardiores.2006.01.026

32. Viatchenko-Karpinski S, Kornyeyev D, El-Bizri N, Budas G, Fan P, Jiang Z, et al. Intracellular $\mathrm{Na}+$ overload causes oxidation of CaMKII and leads to $\mathrm{Ca} 2+$ mishandling in isolated ventricular myocytes. J Mol Cell Cardiol. (2014) 76:247-56. doi: 10.1016/j.yjmcc.2014.09.009

33. Huang X, Du Y, Yang P, Lin S, Xi Y, Yang Z, et al. Age-dependent alterations of voltage-gated $\mathrm{Na}(+)$ channel isoforms in rat sinoatrial node. Mech Ageing Dev. (2015) 152:80-90. doi: 10.1016/j.mad.2015.10.003

34. Song Y, Shryock JC, Belardinelli L. A slowly inactivating sodium current contributes to spontaneous diastolic depolarization of atrial myocytes. Am J Physiol Heart Circ Physiol. (2009) 297:H1254-62. doi: 10.1152/ajpheart.00444.2009

35. Lu YY, Cheng CC, Chen YC, Chen SA, Chen YJ. ATX-II-induced pulmonary vein arrhythmogenesis related to atrial fibrillation and long QT syndrome. Eur J Clin Invest. (2012) 42:823-31. doi: 10.1111/j.1365-2362.2012.02655.x

36. Chen YJ, Chen SA, Chen YC, Yeh HI, Chan P, Chang MS, et al. Effects of rapid atrial pacing on the arrhythmogenic activity of single cardiomyocytes from pulmonary veins: implication in initiation of atrial fibrillation. Circulation. (2001) 104:2849-54. doi: 10.1161/hc4801.099736

37. Hanafy DA, Chen YC, Chang SL, Lu YY, Lin YK, Kao YH, et al. Different effects of dronedarone and amiodarone on pulmonary vein electrophysiology, mechanical properties and $\mathrm{H} 2 \mathrm{O} 2$-induced arrhythmogenicity. Eur $J$ Pharmacol. (2013) 702:103-8. doi: 10.1016/j.ejphar.2013.01.037

38. Nies VJ, Sancar G, Liu W, van Zutphen T, Struik D, Yu RT, et al. Fibroblast growth factor signaling in metabolic regulation. Front Endocrinol. (2015) 6:193. doi: 10.3389/fendo.2015.00193

39. Eswarakumar VP, Lax I, Schlessinger J. Cellular signaling by fibroblast growth factor receptors. Cytokine Growth Factor Rev. (2005) 16:13949. doi: 10.1016/j.cytogfr.2005.01.001

40. Huang C, Liu Y, Beenken A, Jiang L, Gao X, Huang Z, et al. A novel fibroblast growth factor-1 ligand with reduced heparin binding protects the heart against ischemia-reperfusion injury in the presence of heparin co-administration. Cardiovasc Res. (2017) 113:1585-602. doi: 10.1093/cvr/cvx165

41. Lu YY, Lin YK, Wen ZH, Chen YC, Chen SA, Chen YJ. Latrunculin B modulates electrophysiological characteristics and arrhythmogenesis in pulmonary vein cardiomyocytes. Clin Sci. (2016) 130:721-32. doi: 10.1042/CS20150593

42. Heijman J, Voigt N, Nattel S, Dobrev D. Cellular and molecular electrophysiology of atrial fibrillation initiation, maintenance, and progression. Circ Res. (2014) 114:148399. doi: 10.1161/CIRCRESAHA.114.302226

43. Chan CS, Lin YK, Kao YH, Chen YC, Chen SA, Chen YJ. Hydrogen sulphide increases pulmonary veins and atrial arrhythmogenesis with activation of protein kinase C. J Cell Mol Med. (2018) 22:3503-13. doi: 10.1111/jcmm.13627

44. Christophersen IE, Ellinor PT. Genetics of atrial fibrillation: from families to genomes. J Hum Genet. (2016) 61:61-70. doi: 10.1038/jhg.2015.44

45. Chauhan-Patel R, Spruce AE. Differential regulation of potassium currents by FGF-1 and FGF-2 in embryonic Xenopus laevis myocytes. J Physiol. (1998) 512:109-18. doi: 10.1111/j.1469-7793.1998.109bf.x

46. Chen WT, Chen YC, Hsieh MH, Huang SY, Kao YH, Chen YA, et al. The uremic toxin indoxyl sulfate increases pulmonary vein and atrial arrhythmogenesis. J Cardiovasc Electrophysiol. (2015) 26:203-10. doi: 10.1111/jce.12554

47. Burashnikov A, Antzelevitch C. Role of late sodium channel current block in the management of atrial fibrillation. Cardiovasc Drugs Ther. (2013) 27:7989. doi: 10.1007/s10557-012-6421-1 
48. Teng JC, Kay H, Chen Q, Adams JS, Grilli C, Guglielmello G, et al. Mechanisms related to the cardioprotective effects of protein kinase C epsilon (PKC epsilon) peptide activator or inhibitor in rat ischemia/reperfusion injury. Naunyn Schmiedebergs Arch Pharmacol. (2008) 378:1-15. doi: 10.1007/s00210-008-0288-5

49. Lin HY, Lee DC, Wang HD, Chi YH, Chiu IM. Activation of FGF1B promoter and FGF1 are involved in cardiogenesis through the signaling of PKC, but Not MAPK. Stem Cells Dev. (2015) 24:2853-63. doi: 10.1089/scd. 2015.0157

50. Niwa N, Nerbonne JM. Molecular determinants of cardiac transient outward potassium current (Ito) expression and regulation. J Mol Cell Cardiol. (2010) 48:12-25. doi: 10.1016/j.yjmcc.2009.07.013

51. Sutherland-Deveen ME, Wang T, Lamothe SM, Tschirhart JN, Guo J, Li W, et al. Differential regulation of human ether-a-go-go-related gene (hERG) current and expression by activation of protein kinase C. Mol Pharmacol. (2019) 96:1-12. doi: 10.1124/mol.118.115188

52. Pavlovic D, Hall AR, Kennington EJ, Aughton K, Boguslavskyi A, Fuller $\mathrm{W}$, et al. Nitric oxide regulates cardiac intracellular $\mathrm{Na}+$ and $\mathrm{Ca}^{2+}$ by modulating $\mathrm{Na} / \mathrm{K}$ ATPase via PKCepsilon and phospholemman-dependent mechanism. J Mol Cell Cardiol. (2013) 61:164-71. doi: 10.1016/j.yjmcc.2013. 04.013
53. Dhalla NS, Muller AL. Protein kinases as drug development targets for heart disease therapy. Pharmaceuticals. (2010) 3:2111-45. doi: 10.3390/ph3072111

Conflict of Interest: The authors declare that the research was conducted in the absence of any commercial or financial relationships that could be construed as a potential conflict of interest.

Publisher's Note: All claims expressed in this article are solely those of the authors and do not necessarily represent those of their affiliated organizations, or those of the publisher, the editors and the reviewers. Any product that may be evaluated in this article, or claim that may be made by its manufacturer, is not guaranteed or endorsed by the publisher.

Copyright $\odot 2022$ Lu, Cheng, Huang, Chen, Kao, Lin, Higa, Chen and Chen. This is an open-access article distributed under the terms of the Creative Commons Attribution License (CC BY). The use, distribution or reproduction in other forums is permitted, provided the original author(s) and the copyright owner(s) are credited and that the original publication in this journal is cited, in accordance with accepted academic practice. No use, distribution or reproduction is permitted which does not comply with these terms. 